\title{
Explanations of Asset Price Bubbles*
}

\author{
Gergely Lakos - Tibor Szendrei
}

The study provides an overview of the theories explaining asset price bubbles found in the literature. Six different explanations are identified that can cause asset price bubbles on their own as well as in some combination: informational frictions, short selling constraints, limited liability of financial intermediaries, herd behaviour among market participants, perverse incentives in the provision of information, and market participants' bounded rationality. Mispricing arising from asset price bubbles can considerably hamper the efficient allocation of resources, which may warrant government intervention. Nevertheless, most of the underlying factors that induce asset price bubbles can only be limited or offset rather than fully eliminated. Financial stability is mainly threatened by debt-financed asset price bubbles. With respect to asset price bubbles, the mandate and available instruments of macroprudential policy are limited to the mitigation of cyclical fluctuations in the related lending.

Journal of Economic Literature (JEL) codes: G10, G12, R31

Keywords: asset price bubble, excessive lending, bounded rationality, financial stability, macroprudential policy

\section{Introduction}

Bubbles develop in the price of an asset when the asset is substantially overvalued for a relatively long time. Such bubbles can emerge in the price of various assets. ${ }^{1}$ Significant mispricing distorts the allocation of resources, goods and services, resulting in considerable economic losses. In this context, the impact of asset price bubbles which threaten financial stability is the main concern for macroprudential authorities. This is because the build-up of real and financial asset price bubbles may lead to systemic risk in the financial system. When these risks materialise, there is a high probability that the disruptions in the financial intermediary system will considerably damage the overall economy.

\footnotetext{
* The views expressed in this paper are those of the author(s) and do not necessarily reflect the offical view of the Magyar Nemzeti Bank.

Lakos Gergely is a lead economist at the Magyar Nemzeti Bank.E-mail: lakosg@mnb.hu Tibor Szendrei is an economist at the Magyar Nemzeti Bank.E-mail: szendreit@mnb.hu

The Hungarian manuscript was received on 24 March 2017.

DOI: http://doi.org/10.25201/FER.16.4.122150

${ }^{1}$ A comprehensive account of major historical examples can be found, for example, in Kindleberger and Aliber (2011).
} 
The main systemic risks consist of excessive lending risks linked to asset price bubbles. In a developed asset price bubble, economic actors mainly purchase the overvalued asset on credit. During price corrections, the solvency of debtors diminishes, since selling the assets only yields a fraction of the expected income. In addition, the assets concerned are usually the collateral for the loans. Therefore, decreasing asset prices also lower the value of potential collateral pledged when borrowing. Both effects considerably dampen credit demand. Furthermore, asset price corrections also affect lenders negatively, as they incur heavy losses due to part of their loan portfolio becoming non-performing. One method of stabilising their weakened capital position is to curb lending. All in all, when debtfinanced asset price bubbles burst, both credit demand and credit supply may contract considerably. This may even impair the realisation of companies' efficient investment plans as well as households' ability to temporally smooth consumption.

Macroprudential policy can only be effective if we have a proper understanding of the reasons behind the emergence of asset price bubbles. The primary aim of this study is to present the factors identified in the literature. In the case of perfectly rational actors interacting on a perfect market, overvaluation of assets cannot be sustained, since in such a scenario holding the asset yields much lower profits than the cost of purchasing or what can be received by selling it. Therefore, the explanations of asset price bubbles hinge on the presence of investors exhibiting bounded rationality or some imperfection in the market allocation mechanism. In line with the literature, we distinguish five main groups of the latter: informational frictions, short selling constraints, limited liability of financial intermediaries, herd behaviour among market participants, and perverse incentives in the provision of information.

Chapter 2 of the study presents a more accurate definition of asset price bubbles, a key element of which is the definition of the fundamental value. Due to the difficulty in observing the fundamental value, the identification of asset price bubbles in practice poses challenges even in hindsight. This observability predicament is partly the reason why asset price bubbles can emerge. Chapter 3 presents the basic features of the different phases in the asset price cycle. An asset price bubble emerges in the so-called boom phase, and develops during the so-called euphoria period. Chapter 4 gives an overview of the theoretical explanations of asset price bubbles, grouped by explanatory factors. Through the short description of a few relevant theoretical models, the paper illustrates how the different reasons can create asset price bubbles. Since asset price bubbles mainly threaten financial stability when coupled with excessive lending, Chapter 5 briefly discusses why and how the two phenomena can strengthen each other. Finally, the paper summarises the major lessons for state intervention - with a focus on macroprudential policythat can be drawn from the explanations behind debt-financed asset price bubbles. 


\section{Definition of asset price bubbles}

Financial or real assets are overvalued when their market price exceeds the expected present value of the future cash flows and other benefits derived from holding the asset for an extended period of time. The latter is also referred to as the fundamental value and is defined in mathematical form as follows: ${ }^{2}$

$$
F_{t}=\sum_{\tau=t+1}^{\infty} \frac{E_{t}\left(d_{\tau}\right)}{1+r_{t, \tau}}
$$

The fundamental value of the asset in the $t^{\text {th }}$ period is $F_{t} . d_{\tau}$ denotes the monetary value of the profits realised in the $\tau^{\text {th }}$ period, which is uncertain in the $t^{\text {th }}$ period. $r_{t, \tau}$ denotes the expected return on investments in general from the $t^{\text {th }}$ period to the $\tau^{\text {th }}$ period, which also includes the risk premium compensating for the uncertainty of investments. $E_{t}$ is the expected value operator derived from the information available in the $t^{\text {th }}$ period.

Substantial and persistent overvaluation of an asset is commonly referred to as an asset price bubble. ${ }^{3}$ The extent of the price bubble is the difference between the market price and the current fundamental value. Since the fundamental value is the value of uncertain future returns discounted to the present, the fundamental value cannot be observed directly. Identifying exactly what information pertaining to future returns is considered available in the present is already difficult. This is because the various economic actors have different amounts of information with varying degrees of accuracy. This is also influenced by the economic actors' effort to acquire relevant information. It is similarly difficult to observe the extent of uncertainty surrounding potential future returns and to gauge the realistic risk premium expected in exchange for this uncertainty. Due to the above, even with the benefit of hindsight, in practice it is hard to establish whether a bubble emerged in an asset's price or to determine the size of a bubble.

Nevertheless, in several cases, overvaluation or asset price bubbles can be identified with great certainty. One such example is from the study by Huberman and Regev (2001), where the authors examine the price developments of the

${ }^{2}$ This formula is equivalent to the general pricing formula of the asset pricing theory:

$$
F_{t}=E_{t}\left(\sum_{\tau=t+1}^{\infty} m_{t, \tau} d_{\tau}\right)
$$

where $m_{t, \tau}$ is the so-called stochastic discount factor (see Chapter 1 of Cochrane (2005), especially pages 24-25).

${ }^{3}$ The definition of asset price bubbles varies slightly. The definition used in this study is the dominant variety (see Brunnermeier 2008, Brunnermeier-Oehmke 2013, Hirshleifer 2001, Scherbina 2013 and Xiong 2013), although this is not accurate either, since it only roughly distinguishes asset price bubbles from overvaluation. As we detail later, the inaccuracy is due to the fact that these are two very similar phenomena, which primarily differ in their magnitude. 
shares of EntreMed, ${ }^{4}$ a biotech firm, on the market. On 3 May 1998, The New York Times published an article on the development of cancer-treatment medicine, mentioning the name EntreMed several times. In the following weeks, the share price of the company soared from USD 12 to USD 52, in parallel with a steep rise in the volume of trading in the shares. However, EntreMed's research results had already been published in Nature magazine in November 1997, which had also boosted EntreMed's share price, albeit by far less than in May the following year. It is reasonable to claim that the fundamental value of EntreMed shares rose only in November, and therefore a major part of the price increase in May contributed to the emergence of an asset price bubble.

\section{Phases of the asset price cycle}

The starting point in the explanation of asset price bubbles was established by Minsky (1992), and was later detailed by Kindleberger and Aliber (2011). The study divides the asset price cycle into six ${ }^{5}$ phases: displacement, boom, euphoria, profit taking, Minsky Moment, and panic (Figure 1). The theoretical models of asset price bubbles seek to explain this comprehensive asset price cycle. Despite the considerable progress in recent decades, no uniform theory has been devised that is able to accurately and simultaneously capture all the phases of the asset price cycle described by Minsky. In this chapter, Minsky's intuitive characterisation will be reviewed, while the next chapter focuses on describing market imperfections that can cause asset price bubbles to build up and persist.

Displacement is the phase in the life of the asset price cycle when the fundamental value suddenly rises on account of some factor (Figure 2). In the case of stocks, this can occur, for example, when a listed firm develops or uses a more efficient technology, successfully ends a legal dispute, or acquires another company that it can make more efficient through reorganisation. In the case of properties, the fundamental value may rise, for example, when larger employers appear in a given geographical region, which raises the future rents for residential and commercial properties. The asset's market transitions from displacement to the boom phase endogenously.

In the boom phase, the demand for the now undervalued asset rises, lifting the market price and moderating undervaluation. In this period, the economic environment is usually stable; the volatility of asset prices is low, and is coupled with increasing lending and investments. During this stage, the expansion in lending mostly finances investments that seek to utilise the increased efficiency, thus

\footnotetext{
${ }^{4}$ Today, the company is called CASI Pharmaceuticals.

${ }^{5}$ Some divide Minsky's financial instability hypothesis into five phases (see: Brunnermeier and Oehmke 2012), as the Minsky Moment merely refers to a point in time.
} 
boosting the asset's fundamental value. In the case of real assets, this manifests in the production of more real assets, for example the construction of properties. In the case of financial assets, the expansion of activities that ensure future cash flows may be targeted. In the context of stocks, this can take the form of increasing the market share of a listed company using new technology. Often the change that raises the fundamental value is a novelty, the future impact of which is difficult to evaluate, leading to the conundrum of estimating the asset's new fundamental value. Therefore, the asset may be inaccurately priced in the boom phase, making the undervalued asset overvalued.

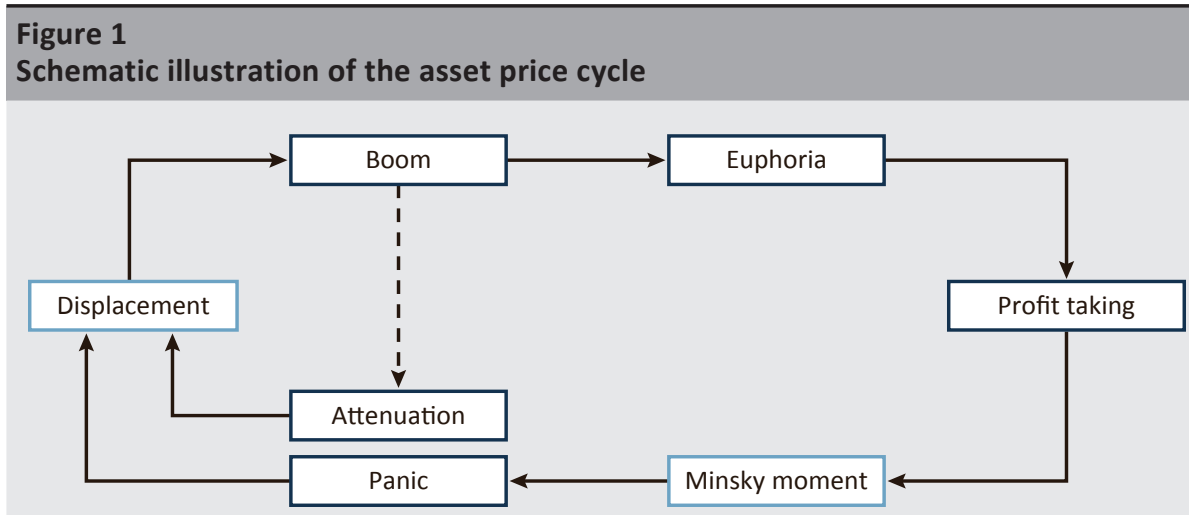

Note: According to the model, the light blue phases of the asset price cycle occur due to exogenous effects.

In the euphoria phase, the overvaluation of the asset increases and persists for a longer period, i.e. the asset price bubble emerges during this stage. The asset price increases steeply, coupled with large price volatility and a high number of transactions. Based on the accelerating price dynamics or due to the fundamental value that is becoming increasingly easy to identify, more and more market participants may realise that an asset price bubble has built up. However, they may have various reasons for holding the asset for some time, thereby sustaining the asset price bubble.

During the euphoria phase, new types of investors appear on the market of the assets. To use Keynes's (1936) terms, professional investors are accompanied by swarms of speculators. The first group was already present on the market of the asset during the boom, and invested in the asset to secure the higher future payments from holding the asset. However, speculators principally purchase the asset in the hope of the expected profit generated from selling the asset later, at a higher price. Demand for the asset is further boosted by the fact that lending may now be used to finance the purchase of the asset, in addition to financing the underlying investments. In the stock example, loans are taken out not only by the companies with increased efficiency to expand their activities, but also by a myriad 
of leveraged investors who purchase shares in the company on credit. The supply of the asset can only catch up to the rapidly expanding demand with a considerable lag, which exacerbates asset price bubbles. One typical example is the world of real estate, where renovations and construction take more time.

It should be noted that the boom phase is not necessarily followed by euphoria, and even if it is, it is not always easy to identify when this happens, even in hindsight. If it becomes clear in time that the asset is slightly overvalued, an investment frenzy is unlikely to occur which would be necessary for the boom period to transition into euphoria. However, if information on the new fundamental value disseminates slower, the probability of the emergence of an asset price bubble is greater; therefore, it is also harder to establish the exact onset of the euphoria phase. Certain characteristics of the asset price bubbles are easier to observe, e.g. the rapid rise in market prices, the related excessive lending or the ensuing distortion in resource allocation. On account of this, the empirical studies on asset price bubbles often identify the bubbles with the help of such variables.

\section{Figure 2}

Development of the market price and the fundamental value in a schematic asset price cycle

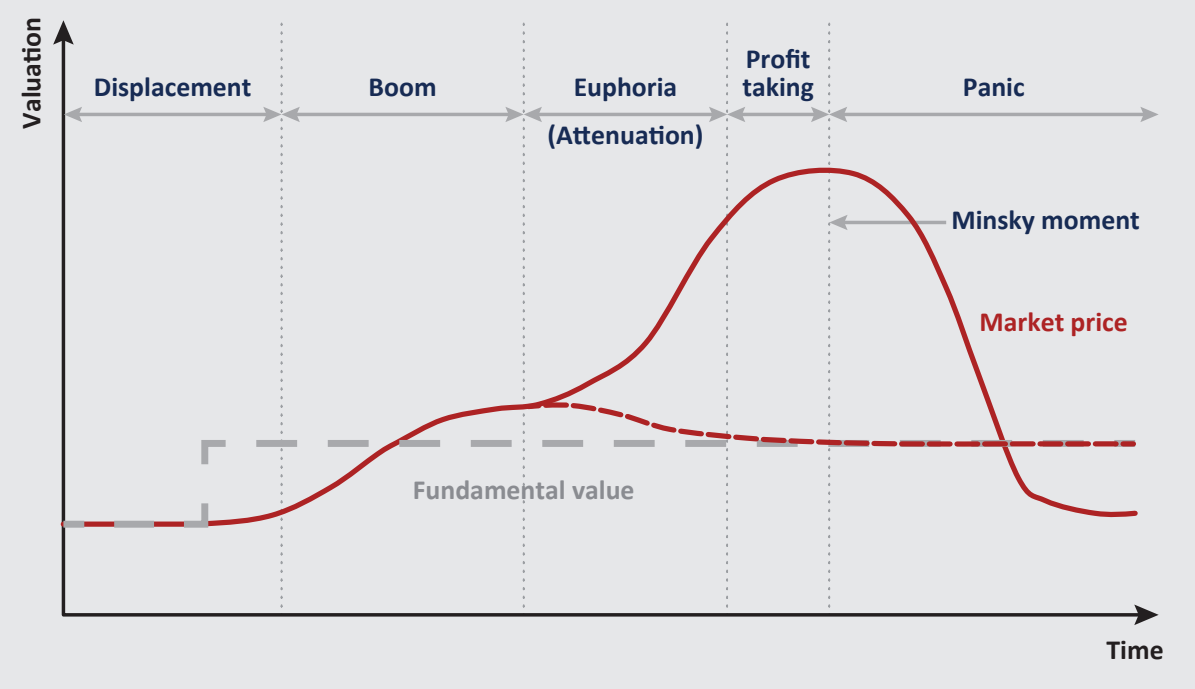

The final stage of euphoria marks the start of profit taking. In this phase, so-called sophisticated market participants, who recognised the asset price bubble earlier, sell the asset, while others do not start selling in large numbers. New actors, mainly speculators, continue to enter the market, who proceed to buy the assets from the sophisticated market participants. Thus, the sophisticated players get a high price for their assets, achieving considerable gains. This is when trading in the asset becomes 
analogous to a Ponzi scheme, since the price is maintained by less sophisticated participants who will probably sell their newly acquired assets at a loss. In practice, isolating the phases of euphoria and profit taking is even harder than delineating the boom and euphoria phases. This is because the withdrawal of capital cannot be accurately observed, and because distinguishing sophisticated market participants from unsophisticated players is even more difficult than identifying fundamental traders and speculators.

The Minsky Moment is an event that impacts market participants' expectations about the future development of the asset price simultaneously, en masse and considerably. As market participants revise their price expectations downwards, panic ensues on the asset's market: market participants seek to sell the asset in large numbers, and the price nosedives, often at a pace exceeding that of the earlier price increase. The intention of selling as soon as possible is rational at the individual level, since the expected price is continuously decreasing, but collectively it results in a suboptimal situation. The resulting price correction is often too large due to the panic, making the asset undervalued. Many are unable to repay the loans amassed in the euphoria phase at the pace stipulated in the loan contract, leading to mass debt problems. The bigger the asset price bubble created by excessive lending in the euphoria phase, the greater the drop in prices, the undervaluation, and the extent of the debt problems.

\section{Reasons behind asset price bubbles}

The theoretical literature has identified six factors that can cause and maintain asset price bubbles in certain combinations: informational frictions, short selling constraints, limited liability of financial intermediaries, herd behaviour among market participants, perverse incentives in the provision of information, and bounded rationality of market participants (Table 1). This chapter presents these in more detail, through the brief introduction of some relevant models. The chapter does not aim to provide a comprehensive review of the literature; it merely undertakes to show examples of how asset price bubbles are formed, using a selection of studies. ${ }^{6}$

\subsection{Informational frictions}

One necessary condition for the price correction of overvalued assets is that enough information about the fundamental values is available on the markets of the assets in a timely manner. The factors hampering the spread of information are called

\footnotetext{
${ }^{6}$ Brunnermeier and Oehmke (2013), Hirshleifer (2001), Scherbina (2013) and Xiong (2013) give a comprehensive overview about the explanations behind asset price bubbles from different aspects.
} 
informational frictions, due to which market participants' beliefs can be persistently disparate. $^{7}$

In the model of Abreu and Brunnermeier (2003), the informational friction is embodied in the phenomenon called sequential awareness. In this framework, the traders do not simultaneously realise when the asset price exceeds the fundamental value, and they do not know when other traders become aware of this. Therefore, the development of the asset price bubble never becomes common knowledge. The other important assumption of the model is that no trader is "big" enough to make a considerable impact on prices with their intention to sell. Thus, for the market price to drop a critical mass of the traders have to recognise that there is an asset price bubble simultaneously and act accordingly by selling at the same time. Since traders forego the extra profits derived from selling later at a higher price by selling too early, the traders who are aware of the asset price bubble are unwilling to part with the asset until this critical mass comes together. However, the requirement of selling together introduces a coordination problem. In such a scenario, all readily observable and perhaps even irrelevant news can cause a selling wave, which entails a rapid correction of the prices and uncertainty regarding the time of the correction. This conclusion is supported by the empirical studies of Cutler et al. (1989) and Fair (2002), where the authors find that most large price movements on the stock exchange did not happen as a result of news pertaining to fundamental values.

\begin{tabular}{l|l}
\begin{tabular}{l} 
Table 1 \\
Factors explaining asset price bubbles \\
\multicolumn{1}{c}{ Explanatory factor }
\end{tabular} \\
\hline Informational frictions & $\begin{array}{l}\text { Beliefs regarding the fundamental value converge } \\
\text { to the real figure too slowly. }\end{array}$ \\
\hline Short selling constraints & The option of short selling is limited. \\
\hline Limited liability & $\begin{array}{l}\text { Financial intermediaries are required to absorb the } \\
\text { losses only to the extent of their capital. }\end{array}$ \\
\hline Herd behaviour & $\begin{array}{l}\text { Market participants excessively imitate each } \\
\text { other's market behaviour. }\end{array}$ \\
\hline Perverse incentives in the provision of information & $\begin{array}{l}\text { There is a conflict of interest for certain } \\
\text { organisations tasked with assessing products and } \\
\text { market participants. }\end{array}$ \\
\hline Bounded rationality & \begin{tabular}{l} 
Market participants are not fully rational. \\
\hline
\end{tabular}
\end{tabular}

\footnotetext{
${ }^{7}$ The extent of persistently different beliefs is difficult to measure directly, however, in line with, for example, the questionnaire-based survey of Mankiw et al. (2004) on the different inflation expectations, we can argue that this phenomenon can truly be significant. Persistently different beliefs can result not only from informational frictions but also from the bounded rationality of market participants. The role of bounded rationality is discussed in Chapter 4.6. One comprehensive overview of the literature on the role of heterogeneous beliefs in the explanations of asset price bubbles can be found in Xiong (2013).
} 
Another type of informational friction is caused by heterogeneous priors. If the initial beliefs regarding the asset's fundamental value differ among traders, they also assess obtainable new information differently. Their beliefs about the fundamental value may differ even if they share all their information with each other. Therefore, even if news on the fundamental value spreads fast on the market, the exaggerated optimism of certain traders only wears off slowly.

With heterogeneous priors, the market price may even exceed the assessment of the most optimistic traders regarding the fundamental value. This is illustrated by the following example which is based on the model by Harrison and Kreps (1978). Let us assume that two types of traders are active on the market for an asset. At the onset of the trading process, all of them believe that the same fundamental value is likely. Next, news about the fundamental value arrives in several waves, until it becomes fully observable. Traders in one group trust their initial beliefs and thus they adjust their beliefs less in response to the new information. In this example, the initial market price of the asset will be higher than the common assessment of the traders. This is because both types of traders can expect lucrative future selling opportunities. If in the subsequent periods good news on the fundamental value arrives, more adaptive traders are willing to purchase the asset even at a higher price than the initial assessment because of the good news. If bad news on the fundamental value arrives, less adaptive traders will still be willing to purchase the asset, even at slightly lower prices than the initial assessment. Accordingly, both types of traders can sell the asset to the other type at a relatively high price precisely at the time when they wish to sell. This mutually beneficial resell option lifts the market price of the asset above the initial assessments.

\subsection{Short selling constraints}

The prospect of pouncing on the arbitrage inherent in a mispriced asset is also hampered by limiting the possibility of short selling. Short selling refers to the immediate selling of a borrowed asset and its return after its future purchase. This makes the selling of an asset available to those who currently do not own enough of it. This trading technique is important because accurate information on the fundamental value does not necessarily reach the market participants who currently hold the given asset in large volumes.

There is often no option for short selling because the market for the given asset is not standardised enough. One typical example is the property market. In other cases, administrative barriers hinder its use. Restrictive measures are usually implemented to avoid a panic due to simultaneous, large-scale short selling, which would make prices fall excessively and rapidly. Bris et al. (2007) analysed the regulations on and the practice of short selling in securities markets of 46 countries between 1990 and 2001, and found that short selling was prohibited in 10 countries during the period reviewed. At the end of the period, it was permitted in 35 countries, but it was 
common practice in only 25 . The lower number of countries where short selling is common practice can be attributed to the fact that in certain countries short selling was hampered by a considerable tax burden.

In Miller's (1977) model, the asset price reflects the beliefs of optimistic traders due to short selling constraints, which makes the asset overvalued. The buying intentions of optimistic traders are reflected in the market price without restrictions, in contrast to the selling intentions of pessimistic traders. Chen et al. (2002) expanded the model and formulated theoretical predictions regarding the impact of short selling on stock prices, which were tested empirically. The study approximated the effectiveness of short selling constraints through the number of shareholders. In the case of fewer owners, it is more likely that market actors who believe the fundamental value to be lower will hold shares in the company in small proportion; therefore, the limits on short selling can take hold more effectively. The authors find that the stocks held by fewer owners yielded lower returns later on, which is consistent with their theoretical conclusion that the limits on short selling make these stocks more overvalued.

\subsection{Limited liability}

Trading in overvalued assets often involves financial intermediaries managing others' savings. Savers usually trust them with their money because financial intermediaries are better at picking good investments. Financial intermediaries can use this information advantage partly to their own advantage and to the detriment of their clients. This practice can be further strengthened by the fact that financial intermediaries share the returns generated by the investments with their clients, but since their liability is limited, they do not have to incur losses in excess of their own capital.

In the model of Allen and Gale (2000), financial intermediaries use debt financing for their activities, i.e. in exchange for these funds they promise interest that is largely independent from their profitability. In such a scenario, it is worthwhile for financial intermediaries to invest in risky assets with high expected returns, since they can retain a larger portion of the potential profit, while they are not obligated to repay their debt in full in the case of losses due to their limited liability. Since lenders are at an information disadvantage compared to the financial intermediaries, they cannot appropriately limit this risk shifting. Excessive risk appetite can generate excessive demand for certain assets, which can lead to the evolution of asset price bubbles.

In the model of Allen and Gorton (1993), there are two types of financial intermediaries both with limited liability but with different levels of sophistication. In the model, the asset price bubble is generated by the less sophisticated financial intermediaries. The difference between the two types of financial intermediaries 
is similar to the distinction made by Keynes (1936) mentioned earlier: more sophisticated intermediaries are able to determine the fundamental value of the assets, while less sophisticated ones cannot. Savers cannot directly observe the quality of financial intermediaries. They pay the financial intermediaries by ceding a fixed share of the money entrusted to them, and in the case of losses, they do not pay the intermediaries anything but incur all the losses. If the less sophisticated financial intermediaries are not active enough on the market, they will reveal to their clients that they are unable to pick the undervalued assets, which could mean the end of their contract. They seek to avoid this, which encourages active behaviour on the market. They do not have to fear buying overvalued assets, since in the event of a potential price correction, their limited liability shields them from large losses anyway.

\subsection{Herd behaviour}

Herd behaviour is when economic actors imitate others' market behaviour too much, in the belief that they will be better off as a result. This process entails wasting the information dispersed among the individual economic actors. In this case, even if the majority believe that an asset price bubble has emerged, they are prone to buying the given asset in line with the trend on the market, thereby contributing to the persistence and potentially further inflating the asset price bubble. Several factors may motivate herd behaviour. Bikhchandani and Sharma (2000) distinguish three types of herd behaviour on financial markets (Table 2): information-based herding, reputation-based herding and compensation-based herding.

\section{Table 2}

Three basic types of herd behaviour

\begin{tabular}{l|l}
\multicolumn{1}{c|}{ Explanatory factor } & \multicolumn{1}{c}{ Content } \\
\hline Information-based herding & $\begin{array}{l}\text { Investors imitate the investment decisions of } \\
\text { others because they believe that the others can } \\
\text { better identify good investments. }\end{array}$ \\
\hline Reputation-based herding & $\begin{array}{l}\text { Investors imitate the investment decisions of } \\
\text { others because this makes them competent in the } \\
\text { eyes of their (potential) employers. }\end{array}$ \\
\hline Compensation-based herding & $\begin{array}{l}\text { Investors imitate the investment decisions of } \\
\text { others because their compensation depends partly } \\
\text { on their performance relative to others. }\end{array}$ \\
\hline
\end{tabular}


In the case of information-based herding, all market participants have information regarding the potential investment decisions that only they can observe (so-called private information). Market participants do not have the time, expertise and other resources available to examine all of the investment opportunities in depth themselves. Therefore, nobody is perfectly informed. Furthermore, the private information obtained by the various actors can be dissimilar. In such a situation, market participants aim to gain an insight into others' private information through their observable behaviour on the market so that they can make the best investment decision.

In the basic models describing information-based herding (Banerjee 1992; Bikhchandani et al. 1992; Welch 1992), assets are traded sequentially, i.e. investors acting later can observe the earlier investment decisions of the other market participants before making their own investment decision. All investors can purchase the same asset at the same prices. Players making the decisions earlier, who engage in similar investments, may easily induce herd behaviour. This is because all investors acting later can deduce that there are many earlier investors whose private information is similar to each other, which can convince them to copy earlier decisions, even if their own private information is contrary to this. In such a scenario, market participants exert negative externalities on those making decisions later. Therefore, the emerging market practice will appropriately reflect the information of only those market participants who make decisions earlier and will not include the private information of those who make decisions later. Investments can be concentrated in certain assets even if the private information of the majority does not substantiate this investment strategy.

Due to the constant asset price assumed in basic models, such models are not suitable for explaining asset price bubbles. However, Avery and Zemsky (1998) have relaxed this assumption. In their model, they examine two types of investors, who can trade in only one asset. Of the two types of investors one has accurate private information regarding the fundamental value of the asset, while the other has access only to inaccurate private information. All investors know their own type, but they do not know exactly what the proportion of well-informed investors to poorly informed investors is on the market. The investment decisions are made sequentially, thus information-based herding can emerge in line with the logic of the basic model. In this model, poorly informed investors imitate the observed earlier investment decisions because they assume that the decisions were made by mostly well-informed investors, even if that was not the case. In such a scenario, the asset price on the market becomes detached from the fundamental value, which may lead to an asset price bubble. 
The basic models of reputation-based herding rest on the assumption that financial experts differ in terms of expertise, experience, diligence, and other qualitative aspects, which cannot be directly observed by their employers. In such situations, the employees seek to perform their duties in a way that their observable performance convinces their current and potential employers that they are better than the others, since this creates better career opportunities for them. However, in certain cases professional reputation can only be improved by imitating other financial experts' investment decisions even if the employees believe that these decisions are not optimal for their employers (Scharfstein - Stein 1990; Trueman 1994; Zweibel 1995; Prendergast - Stole 1996; Graham 1999).

In the model of Scharfstein and Stein (1990), the employed investors all have some private information about the good investment opportunities, independently of each other. The authors distinguish two types of investors: better investors have more accurate private information than bad ones. Each investor has a different employer, but neither investors nor the employers know which investors belong to which category. However, employers can observe the decisions made by all the employees (not only their own), and the profits generated. In such a situation, employers should remunerate their employed investors based not only on the final performance (profits), but also based on how much their decisions differ from other investors' decisions. This is because employers know that the private information of better investors differs less than that of poor investors. If all investors followed their private information, worse investors would be more likely to make decisions deviating from market trends, which would be indicative of their poor quality. Investors strive to avoid this, even if based on their private information they risk making an investment with low returns. Therefore, in equilibrium, investors making sequential decisions can imitate earlier investment decisions, which may generate excessive demand for assets with a lower fundamental value, thereby potentially contributing to the build-up of asset price bubbles.

Zwiebel's (1995) model differs from the previous one in three major assumptions. First, employed investors can be of more than two qualities, and what is even more important, they are aware of their own type. Second, employers cannot observe the quality of the investment decisions made by their employees, only the profits generated from the investments made by their own investors and those employed by others. Third, in this model being a better quality investor does not entail that their private information about investment opportunities is more accurate, instead it merely increases the profitability of all chosen investments deterministically and to the same extent. The large group of average investors making their decisions simultaneously pick the usual investment opportunities, which are in line with earlier market practices, and which are not necessarily the most efficient, because if many investors do so, when employers compare the profits, they can identify 
the relatively good investors quite accurately. Only few investors (the best and the worst) choose investment opportunities diverging from the market practices, therefore their relative performance is more uncertain ex ante. The best trust their excellence, while the worst need to take this risk, since they can only avoid their employers finding out about their poor quality in the event they make a fortuitous investment.

The latter model is a transitional type on the road towards the third group of models, comprising of compensation-based herding models (see, for example, Maug - Naik 1996; Admati - Pfleiderer 1997). In these models, herd behaviour ensues because the remuneration of the employed investors also depends on the observable performance of other, similar investors, i.e. employers use a relative performance assessment system.

In the model of Maug and Naik (1996), employers tie the remuneration of the employed investors to a benchmark on the market, i.e. the more the investors outperform the benchmark, the more their compensation grows. In such a case, imitating the practice widespread on the market can be profitable for risk-averse investors because it reduces the possibility of their performance falling short of the benchmark on the market. This can occur even if based on the private information of a market investor, another investment strategy is expected to yield more profits. Just as in the model of the authors, employers usually use relative performance assessment because they can urge their employees to make greater efforts (tackle moral hazard), and because it helps them select the best candidates (tackle adverse selection), whom they can task with more complex duties. This is because relative performance assessment can be used to pit the individual investors against each other, and better investors exerting more effort outperform others. In other words, employers should use relative performance assessment even if it causes herd behaviour generating poorer investments as an adverse side effect.

\subsection{Perverse incentives in the provision of information}

One group of economic actors are tasked with providing information on certain products and market participants. This is performed, for example, by credit rating agencies, audit companies and financial advisers. If these organisations do not work adequately, the information necessary for the correction of asset price bubbles can spread only slowly. Certain perverse incentives can partly divert the behaviour of economic actors from this basic information provision goal (Scherbina 2013).

According to the study cited, giving a better assessment than warranted about certain firms is worthwhile for financial analysts for various reasons. First, in order to preserve the option of obtaining appropriate information in the future, financial analysts are averse to infuriating the companies under review with negative assessments. Second, the financial analysts of investment banks profit 
from generating transactions for the trading department with a positive stock assessment. Furthermore, in the context of short selling constraints, it is easier to generate trading if the financial analysts make recommendations for more purchases. Scherbina's (2007) empirical study has confirmed that the negative information withheld by financial analysts was incorporated into stock prices with a considerable lag.

The clients of audit organisations and credit rating agencies are usually the companies under review themselves, and they are not interested in making these organisations disclose all the negative information revealed about them. In such a situation, the extent to which audit companies and credit rating agencies perform their job in line with their core function depends on how much they are willing to risk their reputation in the hopes of higher short-term profits. This is because withholding some of the negative information increases their chances of receiving further work from their current clients. However, some of the negative information may become public over time, which undermines the perceived competence and reliability of auditors and credit rating agencies.

\subsection{Bounded rationality}

Despite the fact that asset price bubbles are widely considered to be irrational phenomena, the market imperfections described so far can explain asset price bubbles with the assumption of perfectly rational market participants. Nevertheless, psychological reasons that limit perfect rationality do indeed play a central role in the build-up of asset price bubbles. In the models of behavioural economics, a more realistic decision-maker is assumed instead of a perfectly rational one, i.e. the market participants' ability to process the available information is influenced by the imperfections of memory, attention, calculation skills, and self-control, among other factors. According to another important example, the information reception can also be selective in order to preserve one's own convictions and self-image. The different forms of bounded rationality appearing in the models of behavioural economics are based on empirical psychological results. Decision-makers exhibiting bounded rationality usually create an asset price bubble through their bounded rationality leading to overly optimistic beliefs, which in turn can generate significant purchasing pressure for an overvalued asset. The explanations presented in the study are summarised in Table $3 .^{8}$

\footnotetext{
${ }^{8}$ For a more detailed overview of the models explaining asset price bubbles with the assumption of bounded rationality, see Hirshleifer (2001).
} 


\begin{tabular}{|c|c|}
\hline \multicolumn{2}{|c|}{$\begin{array}{l}\text { Table } 3 \\
\text { Forms of bounded rationality in the presented models }\end{array}$} \\
\hline Explanatory factor & Content \\
\hline Overconfidence & $\begin{array}{l}\text { Investors consider their initial private information } \\
\text { more accurate than it actually is. }\end{array}$ \\
\hline Biased self-attribution & $\begin{array}{l}\text { Investors attribute past successes to themselves } \\
\text { and failures to outside factors. }\end{array}$ \\
\hline Conservativism bias & $\begin{array}{l}\text { Investors change their beliefs less based on new } \\
\text { information as compared to their perfectly rational } \\
\text { peers. }\end{array}$ \\
\hline Representativeness heuristic & $\begin{array}{l}\text { Investors overestimate the probability of the } \\
\text { future occurrence of past events. }\end{array}$ \\
\hline Newswatching & $\begin{array}{l}\text { Investors disregard the portion of others' private } \\
\text { information that can be deduced through } \\
\text { observing market prices. }\end{array}$ \\
\hline Momentum traders & $\begin{array}{l}\text { Investors only take into account the information } \\
\text { discernible from market prices. }\end{array}$ \\
\hline Noise traders & $\begin{array}{l}\text { Investors' beliefs differ to an uncertain extent from } \\
\text { the perfectly rational expected value of the future } \\
\text { market price. }\end{array}$ \\
\hline
\end{tabular}

Daniel et al. (1998) explain asset price bubbles with the combination of overconfidence and biased self-attribution. The essence of overconfidence in the model is that investors regard their private information concerning the fundamental value of the asset to be more accurate than it actually is; biased self-attribution means that investors attribute past successes to themselves and failures to outside factors. In the model, subsequent news confirming the initial private information exacerbates the actors' overconfidence.

Investors perform their own analyses at the beginning of the period under review, thereby gaining private information on the fundamental value of the asset. Later information observable by all investors arrives until the end of the period, making the fundamental value accurately observable. The investors who, based on their private information, assume at the beginning of the period that a value higher than the fundamental value is likely, overreact to the initial information due to their overconfidence, becoming overly optimistic. The public news arriving later can hardly correct this excessive optimism, since overconfident investors trust public news less. In fact, due to biased self-attribution, their excessive optimism is typically heightened even further, since these investors assign greater weight to the new information confirming their initial optimism than contrary information. Over time, the increasing amount of public news convinces everyone about the real fundamental value, but the optimism among the investors exhibiting bounded rationality is greater and more persistent than what would emerge among perfectly rational investors. 
Barberis et al. (1998) explain asset price bubbles with the help of two other assumptions limiting rationality, conservativism bias and representativeness heuristic. Decision-makers characterised by conservativism bias change their beliefs less based on new information than their perfectly rational peers. The decisionmakers following the representativeness heuristic overestimate the probability of events that are noticeably similar to already observed earlier events.

The authors analyse securities, the return of which exhibit random walk over time. Accordingly, the best rational estimate regarding the return for the next period equals the current return. Market investors do not know that the return exhibit random walk and establish their beliefs concerning future returns based on past returns. This process is influenced by the two biases mentioned above. In this model, the excessive optimism regarding future returns and thus the current fundamental value of the securities emerges as follows. If by chance increasing returns are realised in a few consecutive periods, the representativeness heuristic takes hold. The pattern of earlier, similarly increasing returns is easy to remember, and it may indicate to investors that returns are on an upward trend once again. Inevitably, the realised returns will diverge from the assumed trend and conservatism bias can manifest in the investors i.e. they do not update their expectations about the security adequately. Eventually, on account of the returns repeatedly falling short of the expected rising trend, investors update their expectations and assume that the returns fluctuate around a lower average value. This updated expectation is a "conservative" because it assumes that the next period's returns will be closer to the expected average rather than the same value that is currently realised. Ultimately, the excessive optimism is curbed, and the assets' price drops to around the fundamental value.

In the model by Hong and Stein (1999), there are two types of traders exhibiting bounded rationality. So-called newswatchers establish their beliefs on the fundamental value of the asset solely based on the private information derived from the analysis of the asset under review, and they disregard the information from market prices that is otherwise observable. So-called momentum traders do the opposite: they disregard the information pertaining to the fundamental value, and instead estimate the fundamental value of the asset based on the development of market prices observed earlier. In this model, the new positive information pertaining to the fundamental value spreads slowly among investors, since first it only reaches newswatchers who concentrate only on their own information, and not on the potentially new information of other investors. In view of the relatively slow rise in prices, momentum traders can rightly conclude that the asset is undervalued, and thus worth buying. However, since based solely on the price movements they are unable to accurately judge when exactly the undervaluation of the asset ceases, 
the price increase does not stop at the real fundamental value, and overvaluation ensues.

DeLong et al. (1990b) include a perfectly rational trader in a model framework similar to the previous one. The main finding of the analysis is that these traders do not use the opportunity for arbitrage inherent in the asset price bubble created by their peers exhibiting bounded rationality. They are even better off if they exploit their peers' bounded rationality and first make them inflate an even larger asset price bubble. In the model, this can be achieved by increasing demand for the asset more than warranted on account of the initial positive news. This generates a huge initial price increase, which convinces more momentum traders in the next period that the asset should be bought, which drives the price of the asset even higher. The large number of momentum traders entering the market will buy the asset from the rational traders even at this high price, resulting in greater gains than would be possible by not generating extra demand at the beginning of the period. One important lesson from the model is that the asset price bubble engendered by bounded rationality is not necessarily shrunk by the introduction of rational traders, but in fact, it can even be bloated by it.

Perfectly rational traders and those exhibiting bounded rationality are present at the same time in the model of DeLong et al. (1990a) as well. Traders exhibiting bounded rationality are the so-called noise traders who estimate the future expected value of the asset under review inaccurately as compared to rational expectations. The extent of their error is random in all periods, fluctuating around an average; however, this error is persistent in time. If rational traders are riskaverse and impatient enough, they cannot eliminate the overvaluation created by the currently overly optimistic noise traders. Rational traders know that in such a situation the asset should be sold, but they are unwilling to engage in short selling, since that is profitable in the short run only if the market price starts dropping promptly (this is because the borrowed and sold asset has to be bought and given back later). Noise traders remain overly optimistic for a while, and over the short term they can become even more optimistic, which can further increase asset prices. Therefore risk-averse rational traders who heavily discount future profits are prone to putting off large-scale selling until the excessive optimism of noise traders diminishes. In this model as well, the presence of rational traders does not ensure that the overvaluation created by traders' exhibiting bounded rationality disappears through a large-scale selling wave immediately when the mispricing is observed. 


\section{The role of excessive lending}

Excessive lending is the situation where there is a high risk that debtors will not repay a major portion of their loans. Similar to the cyclical development of asset prices, the periods characterised by excessively intensive and subdued lending alternate. According to international experiences, the corresponding phases in asset price cycles and credit cycles are prone to aligning with each other, and when that happens, the cyclical positions are greater than on average (Claessens et al. 2011). Furthermore, asset price bubbles that are linked to excessive lending are more likely to end in a financial crisis (Borio - Lowe 2002) and entail greater losses for the real economy (Brunnermeier - Schnabel 2015; Jordà et al. 2015) than those that are not coupled with excessive lending. Furthermore, the dangerous mix of excessive lending and asset price bubbles can emerge relatively easily if one of them is already present (in the case of properties see: Anundsen - Jansen 2013: Tables 1 and 2; Mian - Sufi 2011). Therefore, excessive lending can considerably exacerbate the adverse effects of asset price bubbles. The focus of this chapter is the reasons behind the emergence of excessive lending related to asset price bubbles, and its effect on the bubbles.

Lending linked to asset price bubbles can easily become excessive for many reasons. One of the main factors is collateral pledged during borrowing. In the case of mortgages, properties are widely used as collateral, just like securities in interbank lending. Loans extended for an overvalued asset as collateral can easily become excessive, since the correction of the asset price over time devalues the collateral, which thus cannot provide adequate compensation to the lender in the case of the debtor's non-performance. Moreover, excessive lending and asset price bubbles can easily reinforce each other's impact. This requires the debtor to invest the loan in the same asset type as the one pledged as collateral. One typical example for this is the mortgage extended for purchasing residential and commercial properties.

The other important reason behind the linkage between excessive lending and asset price bubbles is that the appearance of the bubbles can prompt excessive risk-taking among not only borrowers but also lenders. Excessive lending, i.e. loans provided by lenders to subprime debtors in exchange for inadequate collateral, is only one form of excessive risk-taking. Banks may also be willing to reduce their funding costs just to extend their lending activity. The typical examples for this include disproportionate leverage and overly tight maturity and FX structure. These factors combined can entail significant systemic risk, since in such a scenario an unforeseeable large liquidity need of one of the banks' clients, or a large loss sustained by one of the banks can cause disruption in financial intermediation. 
Excessive risk-taking by banks can be explained by several market imperfections that are partly identical to the reasons behind asset price bubbles. ${ }^{9}$ Investors who wish to invest in an overvalued asset more than their own capital generate large credit demand vis-à-vis financial intermediaries. When assessing loans, even financial intermediaries themselves often try to gauge whether it is worth investing in the given asset, since in certain cases it is known that the loan will finance the purchase of such an asset. In this scenario, lenders are in a similar situation as the economic actors who wish to invest in the asset directly. That is why it comes as no surprise that the limited liability of financial intermediaries can contribute to the emergence of not only asset price bubbles, but also the related excessive lending. Similarly, herd behaviour in lending practices can emerge among banks. Additionally, a banks' management's or owners' bounded rationality can also explain the emergence of excessive lending.

Among the explanations of excessive risk-taking of financial intermediaries there is also an important specific element: larger financial intermediaries can receive various forms of state assistance in the event of systemic stress. In the case of a systemic liquidity shortage, commercial banks can use the central bank as the lender of last resort. Deposit insurance payments protect them from the self-fulfilling bank runs of small depositors. Finally, insolvent financial intermediaries may also receive state capital injections. The instruments of state assistance seek to mitigate the real economy losses of an already developed financial stress. At the same time, they encourage excessive risk-taking on the part of the financial intermediary ex ante, since a large portion of the potential losses are incurred by the state instead of the owners, while the potential profits go to the latter. ${ }^{10}$ State assistance is more likely if multiple financial institutions are in dire state, since such an event threatens the functioning of the financial system as a whole. Therefore, state assistance encourages not only excessive but also correlated risk-taking, thereby strengthening herd behaviour among the institutions.

It is important to note that, according to the empirical literature, the mutually reinforcing processes of asset price bubbles and excessive lending are especially dangerous in the case of residential properties. ${ }^{11}$ Claessens et al. (2012) expanded the study by Claessens et al. (2009) and examined the business and financial cycles

\footnotetext{
${ }^{9}$ For more details, see, for example, Chapter 4 of Freixas et al. (2015).

${ }^{10}$ The resolution of banks on the brink of insolvency is also a form of state assistance, which, in contrast to the other interventions mentioned, reduces the excessive risk-taking of the banking system ex ante. This is because efficient resolution can prevent insolvency, which is often only alleviated with a capital injection by the state. The state-owned organisation in charge of the resolution temporarily assumes the ownership and management rights, and it uses these rights to separate the good assets of the distressed financial institution, and to sell them to other, solvent market participants. Timely reorganisation can steadily maintain the critical functions of the financial institution concerned, for example access to bank deposits and corporate credit lines.

${ }^{11}$ One recent, comprehensive description of the empirical and theoretical results pertaining to the macroeconomic role of residential properties can be found in Piazzesi and Schneider (2016).
} 
of 21 developed OECD countries and 24 emerging countries between 1960 and 2010, and found, among other things, that a rapid drop in housing prices entailed twice as large a decline in GDP on average than other crises. This loss was even greater when the drop in housing prices was coupled with a major contraction of the volume of credit, although the sample contained too few such elements to make the result statistically significant.

Jordà et al. (2015) examined stock prices, housing prices, banking system credit and other macroeconomic data from 17 developed countries between 1870 and 2013. The periods of credit boom coupled with housing price bubbles were more likely to be followed by a recession with financial stress than the periods of mere credit booms. On average, during recessions that were not preceded by asset price bubbles, real GDP per capita declined by approximately 2 per cent (until the trough) in roughly a year, and it took another year for it to return above its initial level. On average, for recessions following housing price bubbles, the trough was reached after around one year as well, and they entailed a similar extent of real economy losses, but a longer recovery given that the housing price bubble was not coupled with rapid credit growth. However, if the recession followed a housing price bubble coupled with a credit boom, real GDP per capita fell even in the second year of the crisis, by about 4 per cent on average before reaching the trough, and it was not able to return to its original level even after three years. Estimates for stock price bubbles yielded similar results between the bubbleless events and the housing price bubble scenarios. All in all, it can be said that the longest and most severe economic crises were preceded by a housing price bubbles coupled with large-scale lending.

Three special features of residential properties make the emergence of a housing price bubbles lead to considerable real economy losses (Crowe et al. 2013). First, housing prices are often prone to becoming decoupled from fundamental values. There are several reasons for this. Homes are not standardised products, they have no standardised market, and many actors are insufficiently informed. The latter is due to the fact that purchasing a home is simultaneously a crucial consumption decision (housing) and a complex investment decision (real asset). In such an environment, the role of informational frictions can be substantial, which hampers the rapid spread of the relevant information on the fundamental value. The high transaction costs incurred during the purchase of a home (e.g. moving, duties, retaining a real estate broker and a lawyer, rebuilding in line with personal preferences) and the uncertain supply reactions due to the time-consuming nature of construction, make identification of the current fundamental value even more complex. In addition, information-based herding can easily emerge among the many insufficiently informed market participants. Average home buyers are not familiar with the methodologies to accurately assess investments; therefore, many rely on 
the naïve extrapolation of past market price developments or similar rules of thumb, i.e. they may be characterised by bounded rationality as well.

Second, normally home purchases are mainly financed from loans with the collateral being the home itself. The price is usually much higher than the average steady income, and therefore external funds are required as well. Furthermore, the home itself is a durable, immovable real asset; hence lenders readily accept it as collateral. Third, homes play a central macroeconomic role. Even without a housing price bubble and excessive lending, homes comprise a huge portion of households' wealth, and mortgages secured with homes comprise a major part of banks' assets. In addition, home construction contributes substantially to GDP and employment.

\section{Conclusions}

\subsection{Asset price bubbles are endogenous phenomena affecting many assets}

The explanations of asset price bubbles note that they do not necessarily emerge and burst as a result of some unexpected shock coming from outside the asset's market. All of the explanations claim that asset price bubbles are the aggregate result of the individually optimal decisions of the economic actors active on the market for the asset. Accordingly, state intervention has to change the decisions of market participants so that the aggregate of the optimal individual decisions creates as small an asset price bubble as possible.

The theoretical literature has identified several reasons behind asset price bubbles. Therefore, state intervention must potentially employ several types of targeted regulatory instruments. The explanations are less specific about what type of real or financial instruments prices are prone to becoming a bubble. Thus, the need for state interventions aimed at the elimination or mitigation of anomalies can arise on several asset markets. According to international experience, asset price bubbles coupled with excessive lending usually threaten greater losses in the real economy, especially in the case of residential properties.

\subsection{Most factors that induce bubbles are difficult to eliminate}

A large part of market participants' bounded rationality cannot be changed. Similarly, the basic reason behind the existence of financial intermediary institutions is that they have more expertise in investments than savers, and if their limited liability was eliminated, few actors would take the elevated business risk, and there would be a significant shortage of a vital service. It is also unlikely that we will have much more accurate and readily available information about future uncertain payments. Therefore, the current fundamental value of assets remains difficult to identify, and the information pertaining to them will not spread faster. Thus, we should always expect informational frictions and information-based herding. 
The incentives due to the information advantage of financial experts are hard to overcome, and therefore reputation-based and compensation-based herding cannot be completely eliminated either. Nonetheless, all the above-mentioned reasons can be constrained or offset to some extent, and state interventions should seek to do so.

Of the reasons behind asset price bubbles the easiest to tackle are short selling constraints and the perverse incentives in the provision of information. The former is often enforced by state regulation, which can be changed, and in the case of stocks several analyses call into question the social benefits of short selling constraints (Marsh-Payne 2012; Beber-Pagano 2013; Boehmer-Wu 2013). Some perverse incentives in the provision of information can be corrected effectively through more efficient regulation, and state organisations can complement the activities of market participants.

\subsection{Partly paternalistic state interventions are necessary}

State intervention has to be partly paternalistic due to the bounded rationality of market participants. As portrayed in the examples of Chapter 4.6, asset price bubbles emerge in line with the desire of most market participants, not as an unintended and adverse side effect of a functioning market. The question in regard to state intervention is of normative basis, since everything happens in line with the expectations of most market participants. Furthermore, the reason behind state intervention can vary depending on the specific form of bounded rationality.

According to one possible approach, the state can reasonably guide decision-makers towards decisions they would probably make themselves if their rationality was not bounded, and if they are willing to shed these constraints (Thaler - Sunstein 2003). One example for this is the excessive optimism arising from limited memory and calculation skills.

\subsection{Lessons for macroprudential policy}

One of the most important state interventions related to asset price bubbles is macroprudential policy which is in charge of preventing and mitigating financial crises. Since asset price bubbles threaten the stability of the financial system through the related excessive lending, it is vital that macroprudential policy identifies when the boom phase of the asset price cycle turns into euphoria, where the asset is increasingly purchased from credit. Identifying the transition in time can help stop excessive lending before it fully unfolds. The spread of herd behaviour, excessive and correlated risk-taking of financial intermediaries with limited liability and the mass entry to the market of less informed and overly optimistic market participants exhibiting bounded rationality all take time. However, once these processes get underway, they can continue to strengthen in a self-reinforcing fashion, which is increasingly difficult to stop and neutralise. 
The explanations of asset price bubbles reviewed also point out that in many respects the overvaluation emerging in the boom phase differs from the asset price bubble developing in the euphoria phase only in its extent rather than qualitatively. They share several reasons, and often the only difference is the time available for the effect of these reasons to take hold. Accordingly, the transition between the two periods is usually smooth and difficult to observe.

Two special factors can be identified that increase the asset's overvaluation primarily in the euphoria phase. The first is the excessive optimism of the market participants exhibiting bounded rationality, which can persist for a long time and thus foster euphoria. The second is excessive lending itself, which is also encouraged by the greater number of actors exhibiting bounded rationality entering the market, and which provides additional funds for boosting demand for the overvalued asset. Therefore, macroprudential policy striving to put an end to excessive lending can only seek to identify one special reason - apart from excessive lending itself behind the euphoria that spread on the market: excessive optimism (or more broadly bounded rationality). Therefore, the euphoria can be mostly identified through the consequences of the asset price bubble rather than the special reasons, for example a rapid rise in market prices, more volatile prices, the increasing number of transactions or the distortion in resource allocation.

Macroprudential policy can efficiently constrain asset price bubbles in certain cases by spreading information pertaining to the fundamental value. Several of the explanations behind asset price bubbles are based on the difficulty of making the information dispersed among market participants widely available. This includes informational frictions, herd behaviour, the perverse incentives of information provision and certain cases of bounded rationality. When monitoring the asset markets concerned, the current overvaluation should be sought to be estimated as accurately as possible. One important aspect here is that the organisation shaping macroprudential policy should not necessarily know more about the fundamental value than what market participants know collectively. It is sufficient if it has incentives to collect this information, even partially, and to make it widely available. This is what the market often performs inadequately.

In other cases, only passing on information is not enough to halt asset price bubbles. This is the case with short selling constraints, the limited liability of financial intermediaries, and asset price bubbles that emerge due to certain types of bounded rationality. In such cases, the primary task of macroprudential policy is to rein in the potential related excessive lending and to mitigate its adverse consequences on the financial system (see, for example, ESRB 2014a: Chapter 3). International experience shows that the so-called debt cap rules are the most effective in curbing excessive lending (see, for example, McDonald 2015; Cerutti et al. 2017, and the references in them). Debt cap rules typically limit the credit amount that can be borrowed by households relative to the value of the collateral or 
income, and they also limit the repayment instalments pledged as a percentage of income. Surplus capital requirements are also used, and they principally strengthen banks' resilience to external shocks. Another important supplementary feature is that they help cover banks' losses on not only household loans but also corporate and project loans.

It may be important from the perspective of the accurate calibration of interventions that in certain cases identifying excessive lending is easier than observing asset price bubbles. For example, according to the ESRB (2014b), various credit-to-GDP figures can be a good measure of excessive lending. The study claims that current values that significantly exceed their long-term trend indicate an amount of credit that makes a financial stress likely in the following couple of years.

\section{References}

Abreu, D. - Brunnermeier, M.K. (2003): Bubbles and crashes. Econometrica, Vol. 71, January: 173-204.

Admati, A.R. - Pfleiderer, P. (1997): Does it all add up? Benchmarks and the compensation of active portfolio managers. The Journal of Business, Vol. 70, July: 323-350. https://doi. org/10.1086/209721

Allen, F. - Gale, D. (2000): Bubbles and crises. The Economic Journal, Vol. 110, January: 236-255. https://doi.org/10.1111/1468-0297.00499

Allen, F. - Gorton, G. (1993): Churning bubbles. The Review of Economic Studies, Vol. 60, October: 813-836. https://doi.org/10.2307/2298101

Anundsen, A.K. - Jansen, E.S. (2013): Self-reinforcing effects between housing prices and credit. Journal of Housing Economics, Vol. 22, September: 192-212. https://doi. org/10.1016/j.jhe.2013.07.001

Avery, C. - Zemsky, P. (1998): Multidimensional uncertainty and herd behavior in financial markets. American Economic Review, Vol. 88, September: 724-748.

Banerjee, A.V. (1992): A simple model of herd behavior. The Quarterly Journal of Economics, Vol. 107, August: 797-817. https://doi.org/10.2307/2118364

Barberis, N. - Shleifer, A. - Vishny, R. (1998): A model of investor sentiment. Journal of Financial Economics, Vol. 49, September: 307-343. https://doi.org/10.1016/S0304405X(98)00027-0

Beber, A. - Pagano, M. (2013): Short-Selling Bans Around the World: Evidence from the 2007-09 Crisis. The Journal of Finance, Vol. 68, January: 343-381. https://doi.org/10.1111/ j.1540-6261.2012.01802.x 
Bikhchandani, S. - Hirshleifer, D. - Welch, I. (1992): A theory of fads, fashion, custom, and cultural change as informational cascades. Journal of Political Economy, Vol. 100, October: 992-1026. https://doi.org/10.1086/261849

Bikhchandani, S. - Sharma, S. (2000): Herd behavior in financial markets. IMF Economic Review, Vol. 47., July: 279-310.

Boehmer, E. - Wu, J.J. (2013): Short Selling and the Price Discovery Process. Review of Financial Studies, Vol. 26, September: 287-322. https://doi.org/10.1093/rfs/hhs097

Borio, C. - Lowe, P. (2002): Asset prices, financial and monetary stability: exploring the nexus. BIS Working Papers, 114. https://doi.org/10.2139/ssrn.846305

Bris, A. - Goetzmann, W.N. - Zhu, N. (2007): Efficiency and the bear: Short sales and markets around the world. The Journal of Finance, Vol. 62, May: 1029-1079. https://doi. org/10.1111/j.1540-6261.2007.01230.x

Brunnermeier, M.K. (2008): Bubbles. In Durlauf, S.N. - Blume, L.E. (Eds.): The New Palgrave Dictionary of Economics, Second Edition, Palgrave Macmillan.

Brunnermeier, M.K. - Oehmke, M. (2013): Bubbles, Financial Crises, and Systemic Risk. In: Constantinides, G.M. - Harris, M. - Stulz, R.M. (Eds.): Handbook of Economics and Finance 2B, Elsevier, pp. 1221-1288. https://doi.org/10.1016/B978-0-44-459406-8.00018-4

Brunnermeier, M.K. - Schnabel, I. (2015): Bubbles and central banks: Historical perspectives. In: Bordo, M.D. - Eitrheim, O. - Flandreau, M. - Qvigstad, J.F. (Eds.): Central Banks at a Crossroads: What can we learn from History? Cambridge University Press, pp. 493-562.

Cerutti, E. - Claessens, S. - Laeven, L. (2017): The use and effectiveness of macroprudential policies: New evidence. Journal of Financial Stability, Vol. 23, February: 203-224. https:// doi.org/10.1016/j.jfs.2015.10.004

Chen, J. - Hong, H. - Stein, J.C. (2002): Breadth of ownership and stock returns. Journal of Financial Economics, Vol. 66, November-December: 171-205. https://doi.org/10.1016/ S0304-405X(02)00223-4

Claessens, S. - Kose, M.A. - Terrones, M.E. (2009): What happens during recessions, crunches and busts? Economic Policy, Vol 24, October: 653-700. https://doi.org/10.1111/j.14680327.2009.00231.x

Claessens, S. - Kose, M.A. - Terrones, M.E. (2011): Financial cycles: What? How? When? In: Clarida, R. - Giavazzi, F. (Eds.): NBER International Seminar on Macroeconomics 2010, The University of Chicago Press, pp. 303-343. https://doi.org/10.1086/658308 
Claessens, S. - Kose, M.A. - Terrones, M.E. (2012): How do business and financial cycles interact? Journal of International Economics, Vol 87, May: 178-190. https://doi. org/10.1016/j.jinteco.2011.11.008

Cochrane, J.H. (2005): Asset pricing, revised edition. Princeton University Press.

Cutler, D.M. - Poterba, J.M. - Summers, L.H. (1989): What moves stock prices? The Journal of Portfolio Management, Vol. 15., Spring: 4-12. https://doi.org/10.3905/jpm.1989.409212

Crowe, C. - Dell'Ariccia, G. - Igan, D. - Rabanal, P. (2013): How to deal with real estate booms: Lessons from country experiences. Journal of Financial Stability, Vol. 9, September: 300-319. https://doi.org/10.1016/j.jfs.2013.05.003

Daniel, K. - Hirshleifer, D. - Subrahmanyam, A. (1998): Investor psychology and security market under- and overreactions. The Journal of Finance, Vol. 53, December: 1839-1885. https://doi.org/10.1111/0022-1082.00077

De Long, J.B. - Shleifer, A. - Summers, L.H. - Waldmann, R.J. (1990a): Noise trader risk in financial markets. Journal of Political Economy, 98(4): 703-738. https://doi. org/10.1086/261703

De Long, J.B. - Shleifer, A. - Summers, L.H. - Waldmann, R.J. (1990b): Positive feedback investment strategies and destabilizing rational speculation. The Journal of Finance, Vol. 45, August: 379-395. https://doi.org/10.2307/2328662

ESRB (2014a): The ESRB Handbook on Operationalising Macro-prudential Policy in the Banking Sector. https://www.esrb.europa.eu/pub/pdf/other/140303_esrb_handbook_ mp.en.pdf. Accessed: 10 October 2017

ESRB (2014b): Operationalising the countercyclical capital buffer: indicator selection, threshold identification and calibration options. ESRB Occasional Paper, 5.

Freixas, X. - Leaven, L. - Peydró, J.L. (2015): Systemic Risk, Crises, and Macroprudential Regulation. The MIT Press.

Fair, R.C. (2002): Events that shook the market. The Journal of Business, Vol. 75, October: 713-731. https://doi.org/10.1086/341640

Graham, J.R. (1999): Herding among investment newsletters: Theory and evidence. The Journal of Finance, Vol. 54, February: 237-268. https://doi.org/10.1111/0022-1082.00103

Harrison, J.M. - Kreps, D.M. (1978): Speculative investor behavior in a stock market with heterogeneous expectations. The Quarterly Journal of Economics, Vol. 92, May: 323-336. https://doi.org/10.2307/1884166 
Hirshleifer, D. (2001): Investor psychology and asset pricing. The Journal of Finance, Vol. 56, August: 1533-1597. https://doi.org/10.1111/0022-1082.00379

Hong, H. - Stein, J.C. (1999): A unified theory of underreaction, momentum trading, and overreaction in asset markets. The Journal of Finance, Vol. 54, December: 2143-2184. https://doi.org/10.1111/0022-1082.00184

Huberman, G. - Regev, T. (2001): Contagious speculation and a cure for cancer: A nonevent that made stock prices soar. The Journal of Finance, Vol. 56, February: 387-396. https:// doi.org/10.1111/0022-1082.00330

Jordà, Ò. - Schularick, M. - Taylor, A.M. (2015): Leveraged bubbles. Journal of Monetary Economics, Vol. 76, December, pp. S1-S20. https://doi.org/10.1016/j.jmoneco.2015.08.005

Keynes, J.M. (1936): The General Theory of Employment, Interest and Money. Palgrave Macmillan.

Kindleberger, C.P. - Aliber, R.Z. (2011): Manias, Panics and Crashes: A History of Financial Crises. Palgrave Macmillan.

Mankiw, N.G. - Reis, R. - Wolfers, J. (2004): Disagreement About Inflation Expectations. NBER Macroeconomics Annual 2003, Vol. 18: 209-248. https://doi.org/10.1086/ma.18.3585256

Marsh, I.W. - Payne, R. (2012): Banning short sales and market quality: The UK's experience. Journal of Banking \& Finance, Vol. 36, July: 1975-1986. https://doi.org/10.1016/j. jbankfin.2012.03.005

Maug, E. - Naik, N. (1996): Herding and delegated portfolio management. IFA Working Paper, 223.

McDonald, C. (2015): When is macroprudential policy effective? BIS Working Papers, 496.

Mian, A. - Sufi, A. (2011): House prices, home equity-based borrowing, and the US household leverage crisis. The American Economic Review, Vol. 101, August: 2132-2156. https://doi. org/10.1257/aer.101.5.2132

Miller, E.M. (1977): Risk, uncertainty, and divergence of opinion. The Journal of Finance, Vol. 32, September: 1151-1168. https://doi.org/10.1111/j.1540-6261.1977.tb03317.x

Minsky, H.P. (1992): The financial instability hypothesis. The Jerome Levy Economics Institute Working Paper, 74.

Piazzesi, M. - Schneider, M. (2016): Housing and Macroeconomics. In: J.B. Taylor - H. Uhlig (Eds.): Handbook of Macroeconomics, Volume 2, North Holland, pp. 1547-1640. 
Prendergast, C. - Stole, L. (1996): Impetuous youngsters and jaded old-timers: Acquiring a reputation for learning. Journal of Political Economy, Vol. 104, December: 1105-1134. https://doi.org/10.1086/262055

Scharfstein, D.S. - Stein, J. C. (1990): Herd behavior and investment. The American Economic Review, Vol. 80, June: 465-479.

Scherbina, A. (2007): Suppressed negative information and future underperformance. Review of Finance, Vol. 12, October: 533-565. https://doi.org/10.2139/ssrn.981063

Scherbina, A. (2013): Asset Price Bubbles; A Selective Survey. IMF Working Paper, 13/45. https://doi.org/10.5089/9781475515299.001

Thaler, R.H. - Sunstein, C.R. (2003): Libertarian Paternalism. The American Economic Review, Vol. 93, May: 175-179. https://doi.org/10.1257/000282803321947001

Trueman, B. (1994): Analyst forecasts and herding behavior. Review of Financial Studies, Vol. 7, May: 97-124. https://doi.org/10.1093/rfs/7.1.97

Welch, I. (1992): Sequential sales, learning, and cascades. The Journal of Finance, Vol. 47, June: 695-732. https://doi.org/10.1111/j.1540-6261.1992.tb04406.x

Xiong, W. (2013): Bubbles, crises, and heterogeneous beliefs. In: Fouque, J.P. - Langsam, J.A. (Eds.): Handbook on Systemic Risk. Cambridge University Press, pp. 664-713.

Zwiebel, J. (1995): Corporate conservatism and relative compensation. Journal of Political Economy, Vol. 103, February: 1-25. https://doi.org/10.1086/261973 